\title{
Хетагурова Д.К. \\ Аспекты формирования образа лирического героя в поэзии символизма (К. Д. Бальмонт, А. И. Токаев)
}

Научно-исследовательский отдел «Центр скифо-аланских исследований» ФГБУН Федерального научного иеетта «Владикавказский научный центр Российской академии наук»

(Россия, Владикавказ)

doi: 10.18411/trnio-11-2021-208

\section{Аннотация}

В статье рассматривается специфика преломления идей символизма в осетинской поэзии конца XIX - начала XX веков (творчество А. И. Токаева). Цель работы - проследить идентичные моменты в формировании образа лирического «Я» А. И. Токаева и К. Д. Бальмонта. В результате анализа выявлены как общие составляющие в характерах лирических героев поэзии Токаева и Бальмонта, так и существенные различия; обозначены возможности решения проблемы эгоцентризма и избранничества. Научная новизна настоящего исследования обусловлена выбранным аспектом анализа в контексте еще недостаточно изученных путей конвергенции осетинской и русской литературы.

Ключевые слова: символизм, Избранный, лирический герой, К. Д. Бальмонт, А. И. Токаев.

\section{Abstract}

The article examines the refraction specifics of the ideas of symbolism in the Ossetian poetry of the late 19th - early 20th centuries (the work of A.I. Tokayev). The purpose of the work is to trace the similar points in the formation of the image of lyrical "I" (A. I. Tokaev and K. D. Balmont). The analysis revealed both common components and significant differences in the characters of the lyrical heroes in Tokayev and Balmont's poetry; the possibilities of solving the problem of egocentrism and selectiveness are indicated. The scientific innovation of this study is conditioned by the chosen aspect of the analysis in the context of still insufficiently studied ways of convergence of the Ossetian and Russian literature.

Keywords: symbolism, Chosen One, lyrical hero, K.D Balmont, A.I. Tokaev.

Любая национальная литература выражает, прежде всего, дух конкретного народа: его традиции, обычаи, верования, одним словом, то, что отличает один этнос от другого. Однако местный колорит - это не единственный формирующий фактор, т.к. всякое искусство находится в развитии, что предполагает обмен и взаимопроникновение традиций других культур.

Возникновение осетинской литературы приходится на конец XVIII - начало XIX веков, в чем немалую роль сыграло присоединение Осетии к России в 1774 году. Поэтому эстетические связи с Россией станут решающими во время расцвета осетинской культуры, пришедшегося на рубеж XIX-XX веков.

Конец XIX века подарил Осетии целую плеяду видных деятелей литературы: К. Л. Хетагуров, С.Гадиев, А. Коцоев, Б. Гуржибеков, А. Кубалов. Именно русская литература «наряду с осетинским фольклором явилась той школой <... художественного мастерства, в которой формировался талант» [6, с. 14] этих писателей. Традиции романтизма, реализма питали национальное искусство. С началом XX века возросло значение поэтики модернизма, а конкретно первого его течения - символизма, чьи идеи были известны в Осетии, и хоть и не привели к созданию отдельной школы, но оказали огромное влияние на лирику А. И. Токаева (1893-1920). 
Токаев - известный осетинский поэт, незаурядный драматург, публицист и художник начала XX. Его наследие занимает видное место в осетинской литературе, хотя и остается по сей день практически неисследованным.

Творчество любого поэта принято делить на этапы. Однако этот принцип не соотносим с наследием А. Токаева. Даже революция 1917 года не внесла серьезных изменений в поэтический мир Алихана Инусовича. Поздние - по времени написания стихотворения отличаются от более ранних мастерством, отточенностью формы, в то время как смысловое наполнение оставалось тем же, что и в предшествующий период. Токаев был верен выбранному аспекту художественных поисков, входящих в сферу символического дискурса.

А.Токаев является новатором осетинского стихосложения - впервые ввел форму сонета («Цыкурайы фæрдыг» - «Бусина желаний»). Токаев обогащает национальную поэзию актуальными «формами, композиционными конструкциями, расширяет стилистические возможности» [3, с. 17], смело экспериментирует, зачастую отказывается от рифмованной структуры («Гуыргæ-Сæфгæ хур» - «Рождающееся-умирающее солнце»), в других случаях звукопись главенствует в смыслонаполнении текста («Марджы взаг» - «Язык ада», «Дымгæ» - «Ветер», «Талынг æмæ Марджы рухс» - «Темнота и Свет яда»).

Поэтика А.Токаева включает в себя те вопросы, которые волновали каждого символиста: жизнь и смерть, свет и тьма, стихийные и солнечные мотивы, идея о Сверхчеловеке, визионерство и тайна сновидений. Эмоциональная окраска таких стихотворений - печаль, весь спектр тонов и полутонов тоски раскрывается автором.

Лейтмотив творчества Токаева - создание образа особенного лирического героя с душой ангела, Сына солнца, того, кто обладает тайными знаниями: «Æз зонын тæхын уæларвмæ, дзурын зæдтимæ, хъазын стъалытимæ, æз атæхин уæларвмæ. Æз зонын хауын дæлдзæхмæ, хъусын æнæбын Дæлдзæхы мæлдзыджыты зарын, æз ныххауин Дæлдзæхмæ.» [7, ф. 276] (Здесь и далее тексты А. Токаева с сохранением авторской орфографии и пунктуации, приводятся в подстрочном переводе автора статьи - Д. $X$.) / «Я умею летать в небесах, говорить с ангелами, играть со звездами, я улетел бы на небо. Я умею падать под землю, слушать в бездонной пропасти песни муравьев, я упал бы под землю».

Подобная личность не чужда и поэзии русских символистов, именно в этом родстве состоит главная общность эстетических установок осетинского поэта и его учителей (К. Д. Бальмонт, Ф. К. Сологуб и др.).

Так, стихотворение «Избранный» (1899) К. Бальмонта начинается такими строками:

О да, я - избранный, я - мудрый, Просвещенный,

Сын Солнца, я - поэт, сын разума, я - царь.. [1, с. 250].

Далее в тексте вырисовывается образ уникального героя, который стоит над миром, он способен постичь тайну мироздания и сокровенную истину. Этот образ рефреном проходит сквозь все творчество поэта: «Не похож на человека, я блуждаю век от века» [Там же, с. 139]. Это строки из стихотворения «Снежные цветы» (1896), настроение преобладающее в нем - равнодушие к людям. Подобная сознательная отстраненность является основой характера лирического «Я» поэзии К.Бальмонта:

Но если еще я пою

Я помню лишь душу мою,

Для вас же давно я погас,

Довольно, довольно мне вас [2, с. 65].

В идеосфере Токаева субъект лирики, наоборот, стремится сокровенные знания отдать людям, спасти их, как мифический герой современности:

Цыргъ кæнын ныр æз мæ кард,

Дурты дæр куыд даса.

Точу я теперь свой меч,

Сурын, сурдзынæн фыддзард, Чтобы даже камни мог рассечь.

Дард йæхи куыд ласа! [7, ф. 145].

Гоню, буду прогонять тяжелую жизнь, Чтобы прочь убиралась! 
Своеобразное рождение такого характера прослеживается в стихотворении «Беспечные люди» - это одно из самых ранних произведений А. Токаева, написанных в годы учебы в Бакинском мореходном училище $(1910-1915)$. Текст построен в форме диалога героя и толпы, открывается оно вопросом к лирическому герою:

Мсен гъеныр диссей фсерсыни:: «Цкемкен сеппарыс де ияард?

Цоемкен дсе фылхуыз, сенкъард?»Мсе фоестке джихсей ксесыни.

Мселлсег хъселсессей зсегъын: «Уседе куылд? Цы кснон ныр сез?

Мое удсен куынсе и фороез

Сыммахау... Зын у ичсрын... [Там же, ф. 162]
Меня теперь удивленно спрашивают: «Почему бросаешь жизнь свою?

Почему ты изможденный, печальный?»-

Вслед мне остолбенело смотрят.

$$
\begin{gathered}
\text { Слабым голосом отвечаю: } \\
\text { «А как иначе? Что мне делать } \\
\text { теперь? } \\
\text { Моя душа не выдерживает } \\
\text { Как ваша...Трудно жить» }
\end{gathered}
$$

Персонаж с другой душой характерен и для поэзии К.Бальмонта:

Моя душа для всех чужая,

Непостижимостью живет [1, с. 330].

Я не из тех, чье имя легион,

$<\ldots>$

В моих зрачках - лишь мне понятный сон [Там же, с. 262].

Следует отметить, что если герой Бальмонта говорит о том, что он «иной» с гордостью, то у А.Токаева он осознает свою избранность без восторга, в недоумении, страдая от осознания своей уникальности.

Антагонистом выступает образ толпы, для которой главная ценность и смысл жизни в меркантильных ценностях и приземленном счастье: ведь если человек не «упитан», то - он «отрекается от жизни». Имеются явные противопоставления: Тело (толпа) - Душа (герой), материальное - идеальное. Главное для толпы - достаток и сытость. Однако герой не признает этих ценностей: «Нæ хъæуы нард минас мæн, / Мæ зæрдæ судзы мæнæн» [5, д. 29, л. 19-20.]. - «Не нужны мне насыщающие пиры / У меня сердце в огне».

Общность в характерах лирических героев Бальмонта и Токаева проявляется в бесконечных поисках и страдании, а причина их уникальности, по словам Константина Дмитриевича: «Я насмерть поражен своим сознаньем, / Я ранен в сердце разумом моим» [1, c. 251]. Ведь человек разумный, мыслящий не может равнодушно смотреть на бесправный мир, где «Уазал, стонг æмæ мæлæт / Бауарзтой мæ бæстæ.» [7, ф. 123] - «Смерть, холод и голод / Полюбили мой край».

Поэтому «горящее сердце» ищет ответов, к которым равнодушно беспечное большинство, поэтому столкновение идеального и материального неизбежно, оттого, поведав тайну своего сердца людям, герой навлек на себя гнев и проклятья. Как писал в стихотворении «Сквозь строй» (1901) К. Бальмонт:

И сильней, все сильней каждый раз,

Вы пугались блистающих глаз.

И вы дрогнули все предо мной,

Увидав, что меж вас - я иной [1, с. 362].

Испугавшись уникальности лирического героя, безликая толпа по старинному обычаю прогнала «прокаженного», побивая камнями:

Мсе фосетое дуртсе сехсыни.

Цкеуын сынджггаий сез дюер.

Фкерыст са дзырдткей мке скер...

Дзурьлнц... Худьлнц... Хсерынц... [7, ф. 162]
Вслед мне камни бросают.

Ухожу медленно ия.

Разболелась голова от их слов... Болтают...Смеются...Едят.... 
Последняя заключительная строфа очень емкая по содержанию и четкая по форме создает уже законченную картину: одиночка, нехотя уходящий от толпы, и «беспечные люди», занятые пустыми, земными делами. Наш герой, напротив, молчит, грустит, он истощен. В финальной строке сконцентрирована главная проблема стихотворения безразличие и глупость человеческая, неспособность понять и задуматься над глубокими вопросами.

Таким образом, в творчестве А. Токаева мы видим, как органически вошла в осетинскую литературу концепция избранничества, популяризируемая русским символизмом, в котором, по словам Л. А. Колобаевой, выражены «претензии личности поднять себя к высшей, Божественной сущности мироздания и уверенность в прямых соответствиях своего “Я” и тайн Вселенной» $[4$, с. 70]. Именно от подобного возвышения и осознания своей особенности возникает конфликтная ситуация в стихотворении А. И. Токаева «Беспечные люди». Однако если в подобной ситуации лирический герой Бальмонта разлад с окружающим миром не переносит болезненно, ведь главная ценность для него «Мое единое отечество - / Моя пустынная душа» [2, с. 58], то Токаевский, напротив, страдает от своей инаковости, от непонимания общества, потому что для него, как и для самого А.Токаева, очень важна связь с Родиной, с горами, с людьми, живущими там, он искренне любит осетинскую землю: «Если бы я обладал Великим Разумом, / Тогда, страдая, боль / Взял бы на себя ради Осетии [5, д. 15, л. 6 ]. Эгоцентризм личности поэзии Бальмонта не свойственен субъекту лирики Токаева, и несмотря на общность мировосприятия и то, что в них обоих заложена трансцендентная способность постичь истину, они отличаются в главном - в расстановке приоритетов познания: «Я» и мир (Бальмонт), мир и «Я» (Токаев).

$$
* * *
$$

1. Бальмонт К. Д. Собрание сочинений: в 7-ми т. М.: Книжный Клуб «Книговек», 2010. Т. 1. 504 с.

2. Бальмонт К. Д. Собрание сочинений: в 7-ми т. М.: Книжный Клуб «Книговек», 2010. Т. 2. 480 с.

3. Джигкаев Ш. Ф. Свет правды и добра. //Антология осетинской поэзии. Орджоникидзе: Ир, 1984. С.7-25.

4. Колобаева Л. А. Русский символизм. М.: Изд-во Московского ун-та, 2017. 352 с.

5. Отдел рукописных фондов Северо-Осетинского института гуманитарных и социальных исследований. Ф. 27. Оп. 1.

6. Салагаева 3.М. От нузальской надписи к роману: Проблемы генезиса и становления осетинской прозы. Орджоникидзе: Ир, 1984. 312 с.

7. Токаты А. Уацмыстæ. Орджоникидзе: Ир, 1973. 308 ф.

\section{Moiseeva A.V. \\ The use of font features as a manifestation of the external side of the emotiogenicity of the text Bashkir State University (Russia, Ufa)}

doi: 10.18411/trnio-11-2021-209

\section{Abstract}

The article describes the graphic features, namely, font combinations that affect the perception and assessment of the text by the recipient. The type of font and its color affects the perception and mental state of a person, because a certain color evokes certain emotions in a person, thus, being a manifestation of the category of text emotiogenicity.

Keywords: graphic features, text perception, emotiogenicity.

\section{Аннотация}

В статье описываются графические особенности, а именно, шрифтовые комбинации, влияющие на восприятие и оценку текста реципиентом. Тип шрифта и его цвета влияет на восприятие и психическое состояние человека, т.к. определенный цвет вызывает у человека определенные эмоции, таким образом, являясь проявлением категории эмоциогенности текста. текста.

Ключевые слова: графические особенности, восприятие текста, эмоциогенность 